\title{
AGRICULTURAL DISPLACEMENT AND SURPLUS LABOR IN THE SOUTH
}

Virgil L. Christian, Jr., and Adamantios Pepelasis*

The economy of the antebellum South, based on labor intensive agriculture rooted in slavery, generated economic, political, social, and moral problems that persist to the present. The Negro's legal status was changed by the Civil War, but his inferior position was quickly embedded in laws and customs developed during Reconstruction. The break from southern agriculture proved to be a slow and tortuous business for the Negro. Manual skills learned on the plantation were not readily transferable to nonagricultural pursuits, and more sophisticated skills were simply not present. The segregated and desperately inadequate school system in the rural South did little to improve the situation, and Negroes continued to penetrate the nonagricultural labor force only in the most menial occupations. And perhaps more fundamentally, new generations of urban Americans, North and South, were conditioned to ascribe only second-class citizenship to the black man as a natural outgrowth of his former bondage and subsequent lowly station in the post-Reconstruction era. As a result, 55 percent of employed Negro males were in agriculture, almost entirely in the South, well past the turn of the century.

The twentieth century brought dramatic changes in American agriculture. The farm labor force declined 29 percent between 1910 and 1940 , from 11.5 million to 8.2 million, then moved rapidly to 5.1 million by 1960.1 Labor displacement in the South paralleled the national trend until World War II. Then it accelerated, with the agricultural labor force falling, by 1969, to one-third of what it had been in $1950 .^{2}$ Blacks were strongly involved in the population and labor movements of the South. At the opening of the century about 90 percent of the American black population lived in the South and more than 80 percent of this population lived in rural regions. Six decades later the South contained something like 60 percent of all blacks of whom 43 percent were inhabiting its rural areas. ${ }^{3}$ More than a half million blacks currently in the nonagricultural labor force were at one time farm workers in the South. Yet agriculture still remains to southern Negroes the most sizeable source of employment. In 1969 agriculture absorbed more black labor than any four nonagricultural industries in the region, aggregated at the 2digit SIC (Standard Industrial Code) level, while black farm ownership actually increased between 1950 and 1969.

The reduction of the farm labor force and the continuing importance of farming to southern Negroes suggest that Negroemployment in southernagriculture should be studied in a larger setting. Specifically, the study should consider the changing role of agriculture within the regional economy; the position of the Negro within agriculture; the capacity of the secondary and tertiary sectors to absorb displaced agricultural labor and the flexibility of such labor in meeting manpower needs outside the primary sector; and finally the adequacy and the plasticity of the institutional framework to facilitate the transition from farm employment to employment in urban markets--both in industry and services.

* The authors are professors of economics at the University of Kentucky; and Virginia Polytechinic Institute and State University. The work is supported by the U.S. Department of Labor. This paper is only a synopsis of our initial findings. It suggests the framework with which our broader research will be conducted. 
However, this paper, being only a reconnaissance with the broader problem, is restricted to preliminaryobservations on the impact of reduced labor intensity in agriculture on regional manpower. The period covered by the data is 1950 to present. Particular emphasis is placed on the ability of the nonagricultural sectors to absorb displaced agricultural surplus. Then a first attempt is made to relate net migration data to the pressure of surplus unskilled labor in the face of a rising demand for skilled labor by the region's growth industries.

Data for the study came primarily from government sources: in particular the 1950 and 1960 Censuses of Population; Current Population Reports and special studies of the Bureau of the Census; the 1949, 1954, 1959, and 1964 Censuses of Agriculture; U.S. Department of Agriculture (U.S. D. A.) publications on farm labor, farm employment, and number of farms; special studies of the Economic Research Service of the U.S.D. A. on labor inputs in agriculture; the one percent work sample of the Social Security Administration. Migration data were drawn from Gladys Bowles'studies on Net Migration of the Population, 1950-1960 and Rashi Fein's 'Educational Patterns in Southern Migration. "4 Labor force estimates came from the Bureau of Labor Statistics publication Employment and Earnings Statistics for States and Areas 1939-1967. ${ }^{5}$ At this point it is worth stressing the inadequacy of data on the dramatic changes in southern agricultureand on the massive black exodus, whichmust have affected social equilibrium in a number of manners. Perhaps moresignificantly, the limited availability of such data and the paucity of research in this area is a sad commentary on ordering priorities, in affluence, and on the interests of the economist and the social scientist.

Our analysis has proceeded on the basis of a number of observed trends and derived propositions. Namely,

1. Labor requirements in agriculture have declined drastically over the last two decades. That is to say, agricultural technology and productivity have led to correspondingly rapid reductions in labor utilization. This has made for large scale displacement of labor away from agriculture. 6 Between 1950 and 1969 the southern agricultural labor force declined by 2, 600,000 workers.

2. Negro labor has been displaced at a rate faster than that of its white counterpart. Such factors as smaller farm size, fewer financial resources, limited access to credit, coupled with less adaptability to changing technology induced a greater outflow of Negro labor.

3. In as much as the marginal product of displaced labor was near zero, such displacement can be taken as an index of surplus labor in southern agriculture. Much of this agricultural labor surplus became surplus for the whole regional economy to the extent that ${ }^{7}$ :

(a) demand for labor throughout the region did not expand sufficiently to absorbincrements in labor force associated with population growth plus ''immigrant" labor;

(b) by and large agricultural labor surplus has been a "non-competing group." Its limited vocational and educational skill-base was lower than that of labor for which there has been a rising demandfrom the industrial sector.

4. As a consequence of educational-skill differences and regional racial attitudes, nonwhites from the surplus agricultural labor pool we re disadvantaged in seeking employment in the nonagricultural sectors of the regional economy, leaving blacks disproportionately represented in the pool of "idle" labor. The dynamics of this pool operated in the direction of pushing away from the region and into the industrialized and urban areas of the country the upper layer of Negro labor.

5. Negro migration must have gained momentum largely because of the rising pressure of the pool of displace labor. Here there has been in operattion a siphonic effect. Displaced farm labor pushing $\rightarrow$ away urban Neg ro labor $\rightarrow$ 
and finding a place for itself in the lower layers of the labor market in the South and then spilling over to the country.

In the fifties some 1.5 million black people migrated away from the South. Net white out-migration was relatively heavy up to 1955; then in-migration was greater than out-migration. ${ }^{8}$ On balance there has been net out-migration (including blacks and whites), but not sufficient to drain off the surplus.

6. Projecting a rising trend in agricultural technology and assuming that the net reproduction rate for the rural South remains relatively high, the southern economy will continue to bear a burden of considerable surplus of low-skill labor. This may suggest that employment and migration patterns for blacks will not be significantly altered during the current decade, though the amount of net migration will undoubtedly decline.

Agricultural Labor Displacement Since 1950

Farm productivity, and in particular of such major crops as cotton and corn, continued to rise considerably throughout the decades of 1950's and 1960 's. 9 This has been caused primarily by the introduction of improved technology in the form of more capital-intensive methods. The U.S.D.A. standard estimates of labor requirements--units of labor required to produce a given amount of output--show a consistent decline in the face of increasing agricultural output. Inevitably, the size of the agricultural labor force--farm operators, family workers, hired workers--shrank following the downward trend of labor requirements. Tables 1 and 2 summarize these data. Table 1 is constructed to show the change in labor requirements in terms of man-hours of standard homogeneous labor units to which all labor has been reduced. Table 2 shows the decline in farm labor for 1950-1969.

At this point it is worth emphasizing that the concept of labor requirements is a non-economic but a technological notion which does not allow for a range of possibilities of varying factor proportions in agriculture. Labor requirements do not, therefore, constitute a demand for labor in as much as demand for laborwould vary with the return per unit of output. ${ }^{10}$ Labor requirements in southernagriculture must have been derived by extending labor requirements of the "average" farm to the whole region and making all fa rming activity conform to that of the average type. Thus measures of labor displacement are mere if not grotesque indices of the order of magnitude of what possibly has happened.

In this light the data of Table 1 reflect technological changes which must have precipitated the displacement of farm labor in the South. Table 2 parallels the rapid technological change. But from the data of these two tables we learn little as to the conditions of demand for and supply of farm labor, the neighborhood of equilibrium in the farm labor market, the level of unemployment, and mostsignificantly the size of surplus labor, i.e., the region of zero or negative marginal product value.

Falling labor requirements led to a downward shift in the demand for farm labor with the consequence that the amount of off-the-farm work performed by farm labor increased. The Censuses of Agriculture of 1954, 1959, and 1964 as well as studies of the U.S.D.A. show this shift clearly. It is asserted that for many marginal or "surplus" farm families the break from dependance on agriculture came in stages: part-time non-farmwork in rural areas; abandonment of farming as the primary source of income; physical movement from the farm. But, apparently, the rate of labor displacement must have been slower than the rate of technologicalimprovements in agriculture. Thus, families who remained on the farm increased the proportion of labortime spent on nonagricultural employment. The data in Table 2 show 
TABLE 1. LABOR REQUIREMENTS IN SOUTHERN AGRICULTURE 1951-1968

\begin{tabular}{lcr}
\hline & $\begin{array}{c}\text { Man-hours } \\
\text { (Millions) }\end{array}$ & Index \\
\hline Year & 6,976 & 100.0 \\
1951 & 6,562 & 94.1 \\
1952 & 6,286 & 90.1 \\
1953 & 5,773 & 82.8 \\
1954 & 5,561 & 79.7 \\
1955 & & \\
& 5,110 & 73.3 \\
1956 & 4,460 & 63.9 \\
1957 & 4,244 & 60.8 \\
1958 & 4,253 & 61.0 \\
1959 & 4,034 & 57.8 \\
1960 & & \\
& 3,904 & 56.0 \\
1961 & 3,704 & 53.1 \\
1962 & 3,609 & 51.7 \\
1963 & 3,360 & 48.2 \\
1964 & 3,148 & 45.1 \\
1965 & & \\
& 2,933 & 42.0 \\
1966 & 2,909 & 41.7 \\
1967 & 2,778 & 39.8 \\
1968 & &
\end{tabular}

Source: U.S., Department of Agriculture, Changes in Farm Production and Efficiency, Statistical Bulletin No. 233 (Washington, D. C.: Government Printing Office, 1969). 
TABLE 2. AGRICULTURAL WORK FORCE IN THE SOUTH 1950-1969 (Thousands)

\begin{tabular}{|c|c|c|c|c|c|c|c|c|}
\hline Year & $\begin{array}{c}\text { Family } \\
\text { workers* }\end{array}$ & Index & $\begin{array}{c}\text { Hired } \\
\text { workers }\end{array}$ & Index & $\begin{array}{r}\text { Total } \\
\text { farm } \\
\text { labor } \\
\end{array}$ & Index & $\begin{array}{l}\text { Decline } \\
\text { from } \\
\text { previous } \\
\text { year }\end{array}$ & $\begin{array}{c}\text { Cumula- } \\
\text { tive } \\
\text { decline }\end{array}$ \\
\hline 1950 & 3,507 & . . & 1,043 & . . & 4,550 & . & . . & . \\
\hline 1951 & 3,340 & 100.0 & 989 & 100.0 & 4,329 & 100.0 & 221 & 221 \\
\hline 1952 & 3,124 & 93.5 & 945 & 95.6 & 4,069 & 94.0 & 260 & 481 \\
\hline 1953 & 2,967 & 88.8 & 934 & 94.4 & 3,901 & 90.1 & 168 & 649 \\
\hline 1954 & 2,848 & 85.3 & 942 & 95.2 & 3,790 & 87.5 & 111 & 760 \\
\hline 1955 & 2,730 & 81.7 & 944 & 95.4 & 3,674 & 84.9 & 116 & 876 \\
\hline 1956 & 2,475 & 74.1 & 904 & 91.4 & 3,379 & 78.1 & 295 & 1,171 \\
\hline 1957 & 2,364 & 70.8 & 898 & 90.8 & 3,262 & 75.4 & 117 & 1,288 \\
\hline 1958 & 2,261 & 67.7 & 921 & 93.1 & 3,182 & 73.5 & 80 & 1,368 \\
\hline 1959 & 2,207 & 66.1 & 939 & 94.9 & 3,146 & 72.7 & 36 & 1,404 \\
\hline 1960 & 2,091 & 62.6 & 903 & 91.3 & 2,994 & 69.2 & 152 & 1,556 \\
\hline 1961 & 2,014 & 60.3 & 931 & 94.1 & 2,945 & 68.0 & 49 & 1,605 \\
\hline 1962 & 1,933 & 57.9 & 892 & 90.2 & 2,825 & 65.3 & 120 & 1,725 \\
\hline 1963 & 1,892 & 56.6 & 879 & 88.9 & 2,771 & 64.0 & 54 & 1,779 \\
\hline 1964 & 1,778 & 53.2 & 784 & 79.3 & 2,562 & 59.2 & 209 & 1,988 \\
\hline 1965 & 1,610 & 48.2 & 721 & 72.9 & 2,331 & 53.8 & 231 & 2,219 \\
\hline 1966 & 1,499 & 44.9 & 635 & 64.2 & 2,134 & 49.3 & 197 & 2,416 \\
\hline 1967 & 1,451 & 43.4 & 580 & 58.6 & 2,031 & 46.9 & 103 & 2,519 \\
\hline 1968 & 1,400 & 41.9 & 551 & 55.7 & 1,951 & 45.1 & 80 & \\
\hline 1969 & 1,350 & 40.4 & 513 & 51.9 & 1,863 & 43.0 & 88 & 2,687 \\
\hline
\end{tabular}

*Includes operators and unpaid family workers.

Source: U.S., Department of Agriculture, Farm Employment, Statistical Bulletin No. 334 (Washington, D. C. : Government Printing Office, August, 1963); U.S. Department of Agriculture, Number of Farms 1910-1959, Statistical Bulletin No. 316 (Washington, D. C.: Government Printing Office, June, 1962); U.S., Department of Agriculture, Farm Labor, U.S. D. A. Crop Reporting Board, 1963 to present (Washington, D. C.: Government Printing Office). Operator and family worker data Number of Farms we re combined with hir-

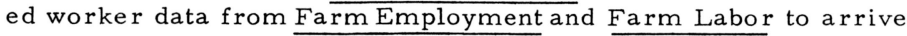
at the totals. 
TABLE 3. FAMILY WORKER AGRICULTURAL EMPLOYMENT, IN MAN-YEARS (THOUSANDS)

\begin{tabular}{lccr}
\hline Year & $\begin{array}{l}\text { Total } \\
\text { family } \\
\text { workers }\end{array}$ & $\begin{array}{c}\text { Total } \\
\text { man-years }\end{array}$ & $\begin{array}{c}\text { Total } \\
\text { man-years } \\
\text { index }\end{array}$ \\
\hline 1950 & $\dot{3}, 340$ & 2,501 & · \\
1951 & 3,124 & 2,315 & 90.9 \\
1952 & 2,967 & 2,105 & 84.1 \\
1953 & 2,848 & 1,946 & 78.5 \\
1954 & & 1,817 & 73.6 \\
1955 & 2,730 & 1,704 & 65.0 \\
1956 & 2,475 & 1,504 & 59.4 \\
1957 & 2,364 & 1,375 & 56.5 \\
1958 & 2,261 & 1,309 & 53.9 \\
1959 & 2,207 & 1,248 & 49.5 \\
1960 & & & 43.9 \\
1961 & 2,091 & 1,146 & 43.3 \\
1962 & 2,014 & 1,017 & 41.3 \\
1963 & 1,933 & 1,003 & 37.9 \\
1964 & 1,892 & 955 & 34.1 \\
1965 & 1,778 & 878 & 31.8 \\
1966 & & & 30.8 \\
1967 & 1,610 & 789 & 29.6 \\
1968 & 1,499 & 736 & 28.6 \\
1969 & 1,451 & 713 &
\end{tabular}

Source: Farm Employment, op. cit.; Number of Farms, op. cit.; and Fa rm Labor, op. cit. Data for reduction to full-time equivalents came from the 1954, 1959, and 1964 Censuses of Agriculture of the U.S. Department of Agriculture. Intercensal year reduction factors were computed by linear interpolation between census years. The calculations were made on a state by state basis for reasons associated with the "Negro Employment in the South" project funded by the U.S. Department of Labor and the Equal Employment Opportunity Commission and directed by F. Ray Marshall. The data in the tables are aggregations of these series. 
TABLE 4. WHITE FAMILY WORKER AGRICULTURAL EMPLOYMENT - SOUTH (Thousands)

\begin{tabular}{|c|c|c|c|c|c|c|c|c|}
\hline \multicolumn{5}{|c|}{$\begin{array}{l}\text { Basic counts } \\
\text { Declin }\end{array}$} & \multicolumn{4}{|c|}{$\begin{array}{c}\text { Ful1-time equivalents } \\
\text { Decline }\end{array}$} \\
\hline Year & Number & Index & $\begin{array}{l}\text { from } \\
\text { previous } \\
\text { year }\end{array}$ & $\begin{array}{l}\text { Cumula- } \\
\text { tive } \\
\text { decline }\end{array}$ & Number & Index & $\begin{array}{l}\text { from } \\
\text { previous } \\
\text { year }\end{array}$ & $\begin{array}{l}\text { Cumula- } \\
\text { tive } \\
\text { decline }\end{array}$ \\
\hline 1950 & 2,741 & 100.0 & . $\cdot$ & . & 1,961 & 100.0 & . & . \\
\hline 1951 & 2,629 & 95.9 & 112 & 112 & 1,830 & 93.3 & 131 & 131 \\
\hline 1952 & 2,478 & 90.4 & 151 & 263 & 1,678 & 85.6 & 152 & 283 \\
\hline 1953 & 2,368 & 86.4 & 110 & 373 & 1,562 & 79.7 & 116 & 399 \\
\hline 1954 & 2,287 & 83.4 & 81 & 454 & 1,469 & 74.9 & 93 & 492 \\
\hline 1955 & 2,203 & 80.4 & 84 & 538 & 1,383 & 70.5 & 86 & 578 \\
\hline 1956 & 2,008 & 73.3 & 195 & 733 & 1,229 & 62.7 & 154 & 732 \\
\hline 1957 & 1,932 & 70.5 & 76 & 809 & 1,129 & 57.6 & 100 & 832 \\
\hline 1958 & 1,864 & 68.0 & 68 & 877 & 1,088 & 55.5 & 41 & 873 \\
\hline 1959 & 1,831 & 66.8 & 33 & 910 & 1,041 & 53.1 & 47 & 920 \\
\hline 1960 & 1,731 & 63.2 & 100 & 1,010 & 958 & 48.9 & 83 & 1,003 \\
\hline 1961 & 1,695 & 61.8 & 36 & 1,046 & 916 & 46.7 & 42 & 1,045 \\
\hline 1962 & 1,635 & 59.6 & 60 & 1,106 & 856 & 43.7 & 60 & 1,105 \\
\hline 1963 & 1,613 & 58.8 & 22 & 1,128 & 822 & 41.9 & 34 & 1,139 \\
\hline 1964 & 1,514 & 55.2 & 99 & 1,227 & 748 & 38.1 & 74 & 1,213 \\
\hline 1965 & 1,389 & 50.7 & 125 & 1,352 & $68 ?$ & 35.0 & 61 & 1,274 \\
\hline 1966 & 1,302 & 47.5 & 87 & 1,439 & 644 & 32.8 & 43 & 1,317 \\
\hline 1967 & 1,217 & 46.4 & 31 & 1,470 & 629 & 32.1 & 15 & 1,332 \\
\hline 1968 & 1,229 & 44.8 & 42 & 1,512 & 607 & 31.0 & 22 & 1,354 \\
\hline 1969 & 1,192 & 43.5 & 37 & 1,549 & 590 & 30.1 & 17 & 1,371 \\
\hline
\end{tabular}

Source: Farm Employment, op. cit. ; Number of Farms, op. cit.; and Farm Labor, op. cit. Data for reduction to full-time equivalents came from the 1954, 1959, and 1964 Censuses of Agriculture of the U.S. Department of Agriculture. Intercensal year reduction factors were computed by linear interpolation between census years. The calculations weremade on a state by state basis for reasons associated with the "Negro Employment in the South" project funded by the U.S. Department of Labor and the Equal Employment Opportunity Commission and directed by F. Ray Marshall. The data in the tables are aggregations of these series. 
TABLE 5. NONWHITE FAMILY WORKER AGRICULTURAL EMPLOYMENT - SOUTH (Thousands)

\begin{tabular}{|c|c|c|c|c|c|c|c|c|}
\hline \multirow[b]{2}{*}{ Year } & \multicolumn{4}{|c|}{$\begin{array}{l}\text { Basic counts } \\
\text { Declir }\end{array}$} & \multicolumn{4}{|c|}{$\begin{array}{c}\text { Full-time equivalents } \\
\text { Decline }\end{array}$} \\
\hline & Number & Index & $\begin{array}{c}\text { from } \\
\text { previous } \\
\text { year }\end{array}$ & $\begin{array}{c}\text { Cumula- } \\
\text { tive } \\
\text { decline }\end{array}$ & Number & Index & $\begin{array}{l}\text { from } \\
\text { previous } \\
\text { year }\end{array}$ & $\begin{array}{l}\text { Cumula- } \\
\text { tive } \\
\text { decline } \\
\end{array}$ \\
\hline 1950 & 767 & 100.0 & . . & . . & 540 & 100.0 & . . & . \\
\hline 1951 & 711 & 92.7 & 56 & 56 & 485 & 89.8 & 55 & 55 \\
\hline 1952 & 646 & 84.2 & 65 & 121 & 427 & 79.1 & 58 & 113 \\
\hline 1953 & 599 & 78.1 & 47 & 168 & 384 & 71.1 & 43 & 156 \\
\hline 1954 & 561 & 73.1 & 38 & 206 & 348 & 64.4 & 36 & 192 \\
\hline 1955 & 527 & 68.7 & 34 & 204 & 321 & 59.4 & 27 & 219 \\
\hline 1956 & 467 & 60.9 & 60 & 300 & 275 & 50.9 & 46 & 265 \\
\hline 1957 & 432 & 56.3 & 35 & 335 & 246 & 45.6 & 29 & 294 \\
\hline 1958 & 397 & 51.8 & 35 & 370 & 221 & 40.9 & 25 & 319 \\
\hline 1959 & 376 & 49.0 & 21 & 391 & 204 & 37.8 & 17 & 336 \\
\hline 1960 & 360 & 46.9 & 16 & 407 & 187 & 34.6 & 17 & 353 \\
\hline 1961 & 319 & 41.6 & 41 & 448 & 162 & 30.0 & 25 & 378 \\
\hline 1962 & 298 & 38.9 & 21 & 469 & 147 & 27.2 & 15 & 393 \\
\hline 1963 & 279 & 36.4 & 19 & 488 & 133 & 24.6 & 14 & 407 \\
\hline 1964 & 264 & 34.4 & 15 & 503 & 130 & 24.1 & 3 & 410 \\
\hline 1965 & 221 & 28.8 & 43 & 546 & 102 & 18.9 & 28 & 438 \\
\hline 1966 & 197 & 25.7 & 24 & 570 & 92 & 17.0 & 10 & 448 \\
\hline 1967 & 180 & 23.5 & 17 & 587 & 84 & 15.6 & 8 & 456 \\
\hline 1968 & 171 & 22.3 & 9 & 596 & 79 & 14.6 & 5 & 461 \\
\hline 1969 & 158 & 20.6 & 13 & 609 & 73 & 13.5 & 6 & 467 \\
\hline
\end{tabular}

Sou rce: Farm Employment, op. cit. ; Number of Farms, op. cit.; and Farm Labor, op. cit. Data for reduction to full-time equivalents came from the 1954, 1959, and 1964 Censuses of Agriculture of the U.S. Department of Agriculture. Intercensal year reduction factors were computed by linear interpolation between census years. The calculations were made on a state by state basis for reasons associated with the "Negro Employment in the South" project funded by the U.S. Department of Labor and the Equal Employment Opportunity Commission and directed by F. Ray Marshall. The data in the tables are aggregations of these series. 
TABLE 6. POPULATION AND LABOR FORCE OF THE SOUTH 1950-1968 (Thousands)

\begin{tabular}{|c|c|c|c|c|c|c|}
\hline \multirow[b]{3}{*}{ Year } & \multicolumn{3}{|c|}{ Population } & \multicolumn{3}{|c|}{ Labor force } \\
\hline & & $\begin{array}{c}\text { Change from } \\
\text { previous }\end{array}$ & $\begin{array}{c}\text { Cumulative } \\
\text { change }\end{array}$ & & $\begin{array}{c}\text { Change from } \\
\text { previous }\end{array}$ & $\begin{array}{c}\text { Cumulative } \\
\text { change }\end{array}$ \\
\hline & Amount & year & from 1950 & Amount & year & since 1950 \\
\hline 1950 & 43,399 & . . & . . & 15,718 & . & . \\
\hline 1951 & 43,661 & 262 & 262 & 15,996 & 278 & 278 \\
\hline 1952 & 44,129 & 468 & 730 & 16,167 & 171 & 449 \\
\hline 1953 & 44,168 & 39 & 769 & 16,181 & 14 & 463 \\
\hline 1954 & 44,464 & 296 & 1,065 & 16,289 & 108 & 571 \\
\hline 1955 & 44,410 & 946 & 2,011 & 16,636 & 347 & 918 \\
\hline 1956 & 46,323 & 913 & 2,924 & 16,970 & 334 & 1,252 \\
\hline 1957 & 47,323 & 1,000 & 3,924 & 17,336 & 366 & 1,618 \\
\hline 1958 & 48,144 & 821 & 4,745 & 17,637 & 301 & 1,919 \\
\hline 1959 & 49,031 & 887 & 5,632 & 17,962 & 325 & 2,244 \\
\hline 1960 & 50,166 & 1,135 & 6,767 & 18,438 & 476 & 2,720 \\
\hline 1961 & 51,044 & 878 & 7,645 & 18,761 & 323 & 3,043 \\
\hline 1962 & 51,908 & 864 & 8,509 & 19,079 & 318 & 3,361 \\
\hline 1963 & 52,788 & 880 & 9,389 & 19,402 & 323 & 3,684 \\
\hline 1964 & 53,593 & 805 & 10,194 & 19,698 & 296 & 3,980 \\
\hline 1965 & 54,411 & 818 & 11,012 & 19,999 & 301 & 4,281 \\
\hline 1966 & 54,873 & 462 & 11,474 & 20,169 & 170 & 4,451 \\
\hline 1967 & 55,582 & 709 & 12,183 & 20,430 & 261 & 4,712 \\
\hline 1968 & 56,275 & 693 & 12,876 & 20,685 & 255 & 4,967 \\
\hline
\end{tabular}

Source: Population data came from the U.S., Department of Commerce, Bureau of the Census, Current Population Surveys (Washington, D. C. : Government Printing Office.) All population figures are for July of their respective years, the 1960 figures having been updated from April 1. Labor force data in 1950 came from the Statistical Abstract of the United States, 1950 (Washington, D. C. : Government Printing Office); in the sixties from the statistical summary in the Manpower Report of the President (Washington, D. C. : Government Printing Office, 1968). 
a greater number of people engaged in farming than the volume of performed work in labor units (man-years). This might betaken as a presumptive evidence of rising underemployment. The counts in Table 2 are at best a grotesque measure of the volume of agricultural labor performed, as they conceal differences in quality of work effort and in length of the workweek. Table 3 corrects in partfor this by converting to man-years. But it fails to adjust labor from heterogeneous sources--male, female, child, young or old--to a common standard. The number of family workers declined from $3,339,000$ in 1951 to $1,351,000$ in 1969 , i. e., by 59.5 percent. But the decline was 71.4 percent in terms of full-time equivalents, i.e., man-years. Clearly, the family worker's employment in man-years terms was smaller in 1969 than in 1951. Furthermore, an increasing proportion of southern farm labor is being performed by hired workers. ${ }^{11}$

\section{Negro Farming}

During the period under consideration, the financial viability of Negro farming has shrunk still further. Operators of small farms have not fared well. And Negroes are concentrated on small farms. The 1959 Census of Agriculture shows that the farm size of Negro full owners was 62 acres or about 38 percent of the farm size of white operators; the size of farms owned partly by Negroes was 83 acres or 18 percent of the corresponding white figure; finally for Negro tenants the size of farm was 35 acres or 18 percent of the white tenant farm size. 12

Or, the average value of land and buildings on fa rms ope rated by Negroes was less than one-fourth of the value of land and buildings on the white farms, i. e., $\$ 6,152$ against $\$ 25,502.13$ U.S. D. A. and Farmers Home Administration loan data reveal much the same adverse position for Negroes, with over 80 percent of loans going to operators of Class V and VI farms--farms having less than $\$ 6,000$ net worth--as opposed to 30 percent for whites, and nearly three-fourths the dollar amount of Negro loans for those classes went for current expenses instead of capital expenditures. For whites nearly two-thirds went for capital. ${ }^{14}$ Finally, the U.S. Commission on Civil Rights presents strong evidence that the agricultural programs of the Federal government have operated unequally for Negro and white farmers in the South. The Farmers Home Administration, the Soil Conservation Service, and the Agricultural Stabilization and Conservation Service all have had, at the state and local level, a segregated structure with strong prowhite orientation. 15

U.S. D. A. estimated in 1962 that "only a handful of southern Negro farmers operate economically viable farms--1.3 percent compared to 13.7 percent of the white farmers" . . . If 'marginally' viable farms are counted, 8. 9 percent of the Negro farms and 26.2 percent of the white farms in the South could be considered adequate or potentially adequate. 16

Tables 4 and 5 show the relative outflow of white and black labor from agriculture between 1951 and 1969. The number of black family agricultural workers declined from 767, 000 in 1950 to 349, 000 in 1960 and 158, 000 in 1969 , a far greater decline in proportion to that of white employment.

It is worth stressing again that the figures in all these tables are used only as indicative of broad trends and changes and cannot be interpreted in any precise manner. Thus, the great decline in the size of the agricultural labor force--white and black--is attributable to number of possible factors one, but only one of which, albeit perhaps the most direct and forceful, is the rapid technologicalimprovements in agriculture. But how much underemployment or open unemployment there was in agriculture, in for example, 
TABLE 7. NONAGRICULTURAL EMPLOYMENT IN THE SOUTH

\begin{tabular}{|c|c|c|c|}
\hline Year & $\begin{array}{c}\text { Total } \\
\text { nonagricultural } \\
\text { employment }\end{array}$ & $\begin{array}{c}\text { Change } \\
\text { from } \\
\text { previous year }\end{array}$ & $\begin{array}{c}\text { Cumulative } \\
\text { change since } \\
1950 \\
\end{array}$ \\
\hline 1950 & $9,809.8$ & . . & . . \\
\hline 1951 & $10,529.5$ & 719.7 & 719.7 \\
\hline 1952 & $10,892.3$ & 362.8 & $1,082.5$ \\
\hline 1953 & $11,063.6$ & 171.3 & $1,253.8$ \\
\hline 1954 & $10,894.3$ & -169.3 & $1,084.5$ \\
\hline 1955 & $11,343.6$ & 449.3 & $1,533.8$ \\
\hline 1956 & $11,853.1$ & 509.5 & $2,043.3$ \\
\hline 1957 & $12,096.8$ & 243.7 & $2,287.0$ \\
\hline 1958 & $12,025.7$ & -71.1 & $2,215.9$ \\
\hline 1959 & $12,450.1$ & 424.1 & $2,640.3$ \\
\hline 1960 & $12,657.1$ & 207.0 & $2,847.3$ \\
\hline 1961 & $12,716.3$ & 59.2 & $2,906.5$ \\
\hline 1962 & $13,157.5$ & 441.2 & $3,347.7$ \\
\hline 1963 & $13,595.1$ & 437.6 & $3,785.3$ \\
\hline 1964 & $14,121.9$ & 526.8 & $4,312.1$ \\
\hline 1965 & $14,934.8$ & 812.9 & $5,125.0$ \\
\hline 1966 & $15,781.0$ & 846.2 & $5,917.2$ \\
\hline 1967 & $16,384.2$ & 603.2 & $6,574.4$ \\
\hline
\end{tabular}

Source: U.S., Department of Labor, Bureau of Labor Statistics, Employment and Earnings Statistics for States and Areas 1939-67, Bulletin No. 1370-5 (Washington, D. C.: Government Printing Office, August, 1968).

1950 or at anyother year and how much more or less of it was in the last year of the time series cannotbe deducted from Table 4 or 5 . The point, however, remains that we assert that the massive exodus of largely displacedagricultural labor must have expanded the size of the surplus labor pool in the southern economy.

Population, Labor Force, Nonagricultural Employment, and Migration

The population of the 14 southern states region increased from $43,399,000$ in 1950 to $55,582,000$ in 1967. The labor force expanded from 15, 718, 000 to 20,430,000, an increase of 4,712,000 workers. During the same period, it is estimated that nonagricultural employment grew from 9, 810, 000 to some $16,384,000$ i.e. by $6,574,000$ jobs. The rate of employment growth was then more rapid than the rate of population and labor growth in the secondary and tertiary sectors. But if we view the entire regionaleconomy, the rate of employment growth lags behind the rate of growth in the active labor force. Between 1950 and 1968 the southern agricultural labor force declined by 2,600,000 thus expanding potential labor availability for employment in industry and services by 140,000 workers annually.

Again, these gross counts and comparisons and the data in Tables 7 and 8 reveal little about the level and changes in underemployment, sectoral or aggregate, the marginal product of labor in various industries, or shortages of labor of certain types. They only present a simple arithmetic difference between potentially available labor--aggregated to cover differences in labor 
skills, origin, and quality--and actual use of labor throughout the regional economy. Indeed this is an inelegant measure. Nevertheless, it may be the best measure available. This difference plus the existing underemployment of labor in agriculture and industry-services suggests the size of the pool of surplus labor.

TABLE 8. ESTIMATE OF SURPLUS LABOR IN THE SOUTH 1967

\begin{tabular}{|c|c|}
\hline \multicolumn{2}{|l|}{ A: Increment in labor force } \\
\hline 1950 to 1967 & $4,712,000$ \\
\hline $\begin{array}{l}\text { B: Decline in farm labor force, } \\
1950 \text { to } 1967\end{array}$ & $2,600,000$ \\
\hline$A+B:$ Sum & $7,312,000$ \\
\hline $\begin{array}{l}\text { C: Rise in nonagricultural } \\
\text { employment, } 1950 \text { to } 1967\end{array}$ & $6,574,000$ \\
\hline$D:(A+B)-C$ & 738,000 \\
\hline
\end{tabular}

Source: Table 2, 6, and 7 of this paper.

The difference $\mathrm{D}$ in Table 8 is composed of individuals who increased the sum $(A+B)$ without increasing $C$, or decreased $C$ without affecting $(A+B)$, or both. ${ }^{17}$ Those in the first group would be basically of three types: post-1950 entrants to the labor force in the nonagricultural sectors who were not employed in 1967; entrants to the labor force in agriculture who were displaced, remained in the labor force, but were unable to find employment in the nonagricultural sectors; member of the 1950 agricultural labor force who left agriculture, remained in the labor force but were not employed in the nonagricultural sectors in 1967. Those affecting $C$ but not A or B would be members of the nonagricultural labor force in both 1950 and 1967 who had, for a variety of reasons including loss of jobs to those leaving agriculture, employment in 1950 but not in 1967.

If the foregoing approach is correct in the main, then the difference, $D$, is made up of surplus labor backed up in the region. This is true because it is net of retirements, deaths, and migration. Since metropolitan labor markets in the South are not particularly loose, the pile-up must be concentrated in the smaller urban centers and in rural non-farm areas. As such, it poses a problem for future displaced agricultural labor in terms of its ability to find nonagricultural employment within the region.

Finally, no strong case should be made for the statistical accuracy or analytical elegance of $\mathrm{D}$, which Table 8 shows as 738,000 . Inevitably, there are discrepancies in the timing of the counts and imprecisions in labor force statistics. The variation might well be one or two hundred thousand either way. It is asserted, however, that this does not affect the essential conclusion that labor displacement from agriculture has led to the massive outmigration, given the limited labor absorptivity of the regional economy and the demand for certain types of skilled labor.

Southerners, black and white, urban and rural, have less education than their occupational counterparts in the rest of the country. And rural Southerners of both races have been exposed to shorter education (in terms of years of schooling) than their urban counterparts. Mary Jean Bowman in her study of southern underdevelopment shows that in 196092.8 percent of farm black males had less than a high school education, 82.2 percent had less than 8 years of education, and 53.3 percent had less than 5 years. For white males the picture was better, albeit low by national averages, the respective percentages being $71.4,46.4$, and 19.0 .18 
Tables $9 \mathrm{a}$ and $9 \mathrm{~b}$ include some of the southern industries (2-digit SIC's) with the highest growth rates over the last two decades and industries with the highest increase in employment. They show the median years of education of their employees.

TABLE 9a. EMPLOYEE INDUSTRIES IN SOUTHERN INDUSTRIES SHOWING RAPID RATES OF GROWTH (1950 to 1960)

\begin{tabular}{lr}
\hline \multicolumn{1}{c}{ Industry } & Years of education \\
Electrical machinery manufacturing & 12.38 \\
Transportation equipment manufacturing & 11.03 \\
Tobacco products manufacturing & 9.06 \\
Mining & 8.04 \\
Personal services & 10.12 \\
Paper and allied products & 10.48 \\
Metal industry manufacturing & 10.78 \\
\hline
\end{tabular}

TABLE $9 \mathrm{~b}^{19}$ EMPLOYEE EDUCATION IN SOUTHERN INDUSTRIES SHOWING LARGE INCREASES IN NUMBER EMPLOYED (1950 to 1960)

\section{Industry}

Professional and related services

Wholesale and retail trade

Construction

Government

Finance, insurance, and real estate

Business and repair services

Apparel products manufacturing

Food and kindred products
Years of education

17.21

11.84

8.8

12.46

12.90

12.29

10.30

9.48

Clearly, the gap between the levels of education and vocational skills of the displaced agricultural labor and the manpower requirements of the growing regional industry was considerable. This is a dramatic case where the unleashing of technological change in agriculture catches southern institutions--and in particular education--at low levels of preparedness to facilitate a new arrangement of productive and human resources. The educational system of the rural South has failed to anticipate the oncoming socio-economic changes and prepare its people--black and white--for their massive relocation and the reallocation of its resources. A regionaleconomic development macro-study which would attempt to investigate the impact of the lowskill-adaptability labor upon the growth and the competitiveness of southern industrial development would perhaps be a useful exercise. In particular, it would be important if it were to measure the social and economic cost of the expanded labor surplus, of the massive migratory movements, and of the social disequilibrium generated by such labor and population movements away from rural into urban areas.

In closing this section, it may be useful to give a bird's eye view of the migratory movements: Out-migration of displaced agricultural workers unable to find employment in the region's nonagricultural sector; in-migration of skilled labor in demand by the new growth industries; on balance, net migration out of the region as employment in the nonagricultural sectors did not expand sufficiently to drain off the agricultural surplus the increment in labor force. Migration data bear these notions out to a considerable degree, as shown in Table 10. The column labelled "South Minus Florida" is more relevant in this context, as net migration to Florida was of such unique character, and of such great magnitude, that it distorts the regional picture. 
TABLE 10. ANNUAL NET MIGRATION FOR THE SOUTH* 1951-1969 (Thousands)

\begin{tabular}{lcr}
\hline Year & $\begin{array}{c}\text { South minus } \\
\text { Florida }\end{array}$ & $\begin{array}{r}\text { Entire } \\
\text { South }\end{array}$ \\
1951 & -95 & +67 \\
1952 & -388 & -257 \\
1953 & -925 & -822 \\
1954 & -784 & -634 \\
1955 & -230 & -52 \\
& & \\
1956 & -230 & + \\
1957 & -144 & +116 \\
1958 & -117 & +81 \\
1959 & -106 & + \\
1960 & +109 & +206 \\
& & \\
1961 & -29 & +311 \\
1962 & -29 & +311 \\
1963 & +56 & +83 \\
1964 & -14 & +48 \\
1965 & +14 & +108 \\
& & \\
1966 & -66 & 2 \\
1967 & +147 & +251 \\
1968 & +66 & +219 \\
\hline
\end{tabular}

*South in this table is for the 11 states of the Confederacy, plus Kentucky, Oklahoma, and West Virginia.

Source: U.S. Department of Commerce, Bureau of the Census, Current Population Reports (Washington, D. C. : Government Printing Office), for the respective years. There was no Report published in 1961. Annual totals accumulated for the ten-year period 1950-1960 check very closely against those presented in Gladys K. Bowles and James D. Tarver, Net Migration of the Population, 1950-1960, by Age, Sex, and Color, U.S. Department of Agriculture, Economic Research Service (Washington, D. C. : Government Printing Office, 1965).

TABLE 11. EDUCATIONAL DISTRIBUTION OF MALE NET MIGRANTS AGES 25-64, COMPOSITE FOR ENTIRE SOUTH 1955-1960

\begin{tabular}{ccr}
\hline Years of schooling & \multicolumn{2}{c}{ Net Migrants } \\
(center of interval) & White & Nonwhite \\
\hline 5 & $-6,200$ & $-6,575$ \\
6 & $-1,981$ & $-9,802$ \\
8 & $+7,307$ & $-6,620$ \\
10 & $+14,111$ & $-10,738$ \\
12 & $+15,044$ & $-8,248$ \\
14 & & - \\
16 and up & $+3,070$ & $-3,167$ \\
& $-77,109$ & $-3,312$
\end{tabular}

Source: Rashi Fein, "Educational Patterns in Southern Migration, "Southern Economic Journal (July 1955), p. 122 and ff. This is a special is sue on "Education and the Southern Economy."

Net migration data are but part of the story. Indeed, netmigration was but the top of the iceberg, with the great bulk not showing. 20 Dividing the South into sub-regions, total migration was 7 times the net migration for white males and 4 times for black males in the South Atlantic states, $81 / 2$ and 2 times, respectively, in the East South Central states, and 11 and $31 / 2$ 
times, respectively, in the West South Central states. Higher educational levels for in-migrants than out-migrants, as expected, are shown though education levels for black Southerners leaving the region was higher than for those who remained.

In-migrants have had higher educational levels than out-migrants, as expected. But the black migrant from the South has hadrore education than the black who remained in the region. ${ }^{21}$ This then may be taken as apresumptive evidence of the composition of the migrant group, the shift of occupational patterns, and of the educational distribution of the southern labor force. If the displaced agricultural workers were the migrants out of the South, they were indeed the pick of the lot. Their educational levels were clearly higher than those of the rural male blacks of the region. But there is little information on the levels of education of those actually displaced from agriculture. Prima facie, we would, however, argue that the educational levels of the displaced labor would be lower than the regional rural education level. It is, the refore, asserted that the out-of-region migrants were, in the main,urban blacks who were pushed out by the low educational level blacks and whites who were initially pushed away from agriculture.

In this initial report we have related technological changes in agriculture to labor displacement. We suggest that southern migration to southern and northern urban areas should be investigated, in first approximation, in terms of structural changes in agriculture and the rates of changes in the demand for certain types of labor in the secondary and tertiary sectors of the region.

The next phase in our research is designed to test,supplement, and expand our findings, hypotheses, and present conclusions. Finally, we will examine the conditions of the Negro in southern agriculture and the implications of his movements away from it. This examination will be derived primarily from an analysis of the changes in the crop-mix in southern agriculture, the consequent changes in skills required, and the manpower needs in the region. The historical review of the changing position of black labor will then be supplemented with an analysis of projected conditions of the demand for the major crops, projected changes in agriculture technology, and projected rates of growth in the urban markets. All will be studied within the broader problem of institutional changes and public policies. 
${ }^{1}$ Dale L. Hiestand, Economic Growth and Employment Opportunities for Minorities (New York: Columbia University Press, 1964), pp. 7-9. Basic data are from the U.S., Department of Commerce, Bureau of the Census, Censuses of Population (Washington, D. C. : Government Printing Office).

${ }^{2}$ Mechanization of cotton accounted for much of the acceleration. The proportion of cotton harvested by hand fell from 92 percent in 1950 to 11 percent in 1966.

${ }^{3}$ M. Hayes, "A Century of Change in the U.S. Economy 1860-1960," Monthly Labor Review (December 1962), pp. 1356-65. Also, DavidKaun, "Negro Migration and Unemployment, "Human Resources (Spring 1970).

${ }^{4}$ Complete references are given at the appropriate place in the text.

${ }^{5}$ It was necessary, of course, to cumulate these data state by state, year by year. Our South is composed of the 11 states of the Confederacy plus Kentucky, Oklahoma, and West Virginia.

${ }^{6}$ Surplus labor may be defined as the difference between labor available (the labor time that the agricultural population can provide under full employment) and labor required, given the area under cultivation, capital, technology, and the volume of output produced. The concept of chronic surplus labor refers to that part of the labor force, then, which could be removed without a decrease in total farm output--given the level of technology applied. Operationally, labor becomes surplus and is pushed out of agriculture when its marginal product falls below the family subsistencelevel. The technology of agriculture has changed so rapidly, and become so much more capital intensive, that a significant proportion of labor used profitably one year becomes surplus the next. This has been particularly true in the South's biggest crop--cotton.

7 Technically, unskilled labor becomes surplus in the region when its marginal product reaches zero in all sectors. Operationally, it becomes surplus at a level analogous to that defined for farm labor.

${ }^{8}$ This is true even if Florida is netted out. In-migration to Florida has been considerable throughout the post-World War II period.

${ }^{9}$ U.S., Department of Agriculture, Changes in Farm Production and Efficiency, Statistical Bulletin No. 233 (Washington, D. C.: Government Printing Office, 1969).

${ }^{10} \mathrm{M}$. Desai and D. Muzumdar, "A Test of the Hypothesis of Disguished Unemployment, "Economica (February 1970), pp. 39-40.

${ }^{11}$ The labor force counts in Table 2 show only 41.9 percent as many operators and family workers in 1968 as in 1951, while the corresponding percentage for hired workers is 55.7. This reinforces the much clearer comparison that can be derived from Tables 1 and 3, which show that labor requirements in 1968 were 39.8 percent of those in 1951, but that operator and family worker input was only 29.6 as great.

${ }^{12}$ U.S., Department of Agriculture, 1959 Census of Agriculture, Volume 
II, Chapter X, Table 7 (Washington, D. C. : Government Printing Office).

13 James D. Cowhig and Calvin L. Beale, "Socioeconomic Differences Between White and Nonwhite Farm Populations of the South, "Southwestern Social Science Quarterly (September 1964).

${ }^{14}$ U.S. , Commission on Civil Rights, Equal Opportunity in Farm Programs (Washington, D.C.: Government Printing Office, 1965, p. $69 \mathrm{ff}$.

${ }^{15}$ Ibid. As one striking example, the report states that of 3, $600 \mathrm{Farm}-$ ers Home Administration state and county committeemen under Federal appointment in 1962 none were Negroes, and in late 1964 there were but 125 , 100 of whom served only as alterriates.

${ }^{16}$ Ibid. , p. 9.

${ }^{17}$ It might be worth pausing at this point to inquire into the extent to which the difference between labor available and labor required measures surplus labor by looking at the counting process.

First, it should be noted that members of the regional farm labor force in 1950 but who migrated, died, or retired before 1967 reduced A, increased $B$, and thus have been netted out of $D$.

Second, workers who entered the agriculture labor force after 1950 and late $r$ shifted into nonagricultural employment in the region would be counted under $A$ and $C$ and would not affect the size of $B$.

Third, the number of farmers who entered the labor force after 1950 , then shifted to nonagricultural employment and finally left the region do not affect A, B, C, or D. These individuals we re not members of the labor force either in 1950 or 1967. D fails to capture this case and thus it understates the pressures generated by agricultural displacement. This is somewhat similar to the first case. D would have been greater if the se individuals had not responded to the pressures of dwindling employment opportunities by leaving the region, thus not adding further to the pool of regional unemployment and underemployment.

${ }^{18}$ Mary Jean Bowman, "Human Inequalities and Southern Underdevelopment, "The Southern Economic Journal Supplement on Education and the Southern Economy (July 1965), p. 75. The basic data are from the 1960 Census of Population of the U.S. Department of Commerce, Bureau of the Census (Washington, D. C.: Government Printing Office).

${ }^{19}$ Data are from the U.S., Department of Commerce, Bureau of the Census, 1960 Census of Population (Washington, D. C. : Government Printing Office). The median years of schooling were taken for the typical SIC in each case. The complete picture is as follows: professional and related services (SIC's 80 and 81 ), 17.21 and 17.31 years, respectively; wholesale and retail trade (50 and 53), 11.84 and 12.03 ; construction (15, 16, and 17). $8.80,8.80$, and 8.80; government $(91,92$, and 93), 12.46, 12.53, and 11.15 ; finance, insurance, and real estate $(60,62$, and 65), 12.90, 14.55, and 12. 06; business and repair service (73 and 76), 12.29 and 10. 34; apparel products manufacturing (23), 10.30; food and kindred products (20), 9. 48 .

${ }^{20}$ Rashi Fein, "Educational Patterns in Southern Migration, "Southern Economic Journal (July 1965), p. $122 \mathrm{ff}$.

${ }^{21}$ Access to information relating to higher lifetime income and responsiveness to economic incentives may be assumed to va ry positively with the level of schooling. Samuel Bowles, in his excellent and rigorous paper on "Migration as Investement," has formulated and tested a hypothesized 
model of migration. One of his hypotheses is that the effect on the migration rate of the present value of the expecte? income gain as a result of migrating is a positive function of the level of education. Samuel Bowles, "Migration as Investment: Empirical Test of the Human Investment Approach to Geographical Mobility, "Review of Economics and Statistics, Vol. LII, No. 4 (November 1970), pp. 356-362. 